\title{
DETERMINATION OF FAECAL GESTAGENS IN SOWS BY COMMERCIAL PROGESTERONE EIA KIT
}

\author{
T. SNOJ, N. CEBULJ-KADUNC, T. PARDUBSKY, V. CESTNIK
}

Institute of Physiology, Pharmacology and Toxicology

Veterinary Faculty, Ljubljana, Slovenia

Received January 13, 1998

Accepted March 3, 1998

\begin{abstract}
Snoj T., N. Cebulj-Kadunc, T. Pardubsky, V. Cestnik: Determination of Faecal Gestagens in Sows by Commercial Progesterone EIA Kit. Acta vet. Brno 1998, 67: 21-25.

The aim of the study was to test the applicability of commercial progesterone enzyme immunoassay (EIA) kit for faecal gestagen determination in sows. Faecal and blood samples were collected every second day from oestrus until d 16, and every day from d 16 until d 21 of oestrous cycle or pregnancy. Extraction of gestagens from faeces was performed by methanol. Faecal gestagen and plasma progesterone concentrations were measured by Ovucheck 96 Well Plasma/Serum Progesterone EIA kit. Changes in faecal gestagen (progesterone and its metabolites) concentration during the oestrous cycle or pregnancy significantly correlated with plasma progesterone levels. Faecal gestagen concentrations on days 20 and 21 of oestrous cycle were 2148 \pm 474 and $1961 \pm 65 \mathrm{nmol} / \mathrm{kg}$. In the same period of pregnancy faecal gestagen concentrations were $7624 \pm 8$ and $7468 \pm 106 \mathrm{nmol} / \mathrm{kg}$, respectively. In pregnant animals, the faecal gestagen concentrations were significantly higher $(\mathrm{P}<0.01)$ than in non-pregnant ones. The results indicate that measurement of faecal gestagens in sows by using commercial EIA kit is suitable for progesterone status detection in healthy animals, but is not appropriate in animals suffering from diarrhoea.
\end{abstract}

Gestagens, progesterone, diarrhoea, oestrous cycle, pregnancy, swine

After completing their function in the organism steroids are deactivated by glucuronate and sulphate conjugation in the liver and excreted in urine by the kidneys or via bile released into the gut (Taylor 1971). However under the influence of intestinal bacteria the steroids in the gut are deconjugated, partially reabsorbed and partially excreted by faeces. In pigs evident enterohepatic circulation of steroids has been described (Ru off and Dziuk 1994; Symonds et al. 1994). After $14 \mathrm{C}$ progesterone administration in pigs, $34 \%$ of the radioactivity is excreted by faeces and $66 \%$ by the urine (Palme et al. 1996). The main progesterone faecal metabolites in sows are: 20-oxo-pregnanes $(50.1 \%), 20$-b-hydroxy pregnanes $(24.2 \%)$, 20-a-hydroxy pregnanes $(18.9 \%)$ and unidentified metabolites $(7.5 \%)$. Only about $1 \%$ of the administered progesterone is excreted in unmetabolised form (Palme et al. 1997).

Determination of steroid hormones in faeces has been described in many species. Detection of pregnancy by measuring oestrogens in faeces was demonstrated in ewes after day 88 (Busch and Bamberg 1990), in mares after day 120 (Youngblood and Williams 1987; Palme et al. 1989) and in sows between day 25 and 30 (Szenci et al. 1993). Significant positive correlation between plasma and faecal gestagens was observed in cows (Schwarzenberger et al. 1990) and in cycling sows (Hulten et al. 1995). The measurement of faecal steroid hormones is sometimes the only suitable method for the 
detection of pregnancy or oestrous cycle in zoo ( $\mathrm{S}$ a far-Hermann et al. 1987; Wasser et al. 1988: Schwarzenberger et al. 1996) and free ranging animals (W as ser et al. 1991).

The measurement of faecal steroids in sows has at least two advantages. The collection of faecal samples is easier than venepuncture and the animals are not subjected to stress.

Ovucheck 96 Well Plasma/Serum Progesterone EIA kit is a commercial product used for oestrus detection and assessment of pregnancy status or luteal function in cows, sows, goats and it was also validated for horses, sheep and dogs (Eckersall and Harvey 1987).

The aim of the study was to:

1. test the applicability of the commercial progesterone EIA kit for the measurement of feacal gestagens (progesterone and its metabolites) in sows,

2. follow the oestrous cycle dynamics,

3. compare the faceal and blood gestagen concentrations.

\section{Materials and Methods}

\section{Animals}

The investigation was performed on 17 mature hybrid sows (Sus scrofa) aged from 14 months to 4.5 years, kept in individual pens. Two animals were followed through the 21 -day oestrous cycle and 15 animals from insemination to the $21 \mathrm{st}$ day of pregnancy. The animals were fed twice daily approximately $1 \mathrm{~kg}$ of commercial diet mixture containing: barley $35 \%$, maize $24.46 \%$, wheat meal $12 \%$, soya bean meal $7.48 \%$, fish meal $6.88 \%$, alfalfa $6.50 \%$, dried beet pulp $6 \%$, mollases $0.05 \%$, mineral-vitamin addition $1.62 \%$ and water ad libitum.

\section{Sampling}

From the beginning of oestrus to the 16th day of oestrous cycle or pregnancy the faecal and blood samples were taken every second day and daily in the period from the 16th to 21 st day. Until analysed, faecal and plasma samples were kept frozen at $-20 \mathrm{oC}$. Diarrhoea was permanently observed in two animals and temporary in two others.

\section{Faecal gestagen analysis}

Extraction of faecal gestagens was performed by methanol as described by Möstl and coworkers (Möstl et al. 1993). Extracts were diluted in proportion 1:20 with buffer solution ( $\mathrm{pH} 7.4$ ) containing: $\mathrm{Na}_{2} \mathrm{HPO}_{4} 12.21 \mathrm{~g}$, $\mathrm{NaH}_{2} \mathrm{PO}_{4} \times 2 \mathrm{H}_{2} \mathrm{O} 2.18 \mathrm{~g}$, gelatine $1.00 \mathrm{~g}, \mathrm{NaN}_{3} 0.50 \mathrm{~g}$, in $1 \mathrm{~L}$ of distilled water.

Measurement of gestagens (i.e. progesterone and its metabolites) in diluted faecal extracts was done by following the original instructions for progesterone determination in serum or plasma as described in the Ovucheck 96 Well Plasma/Serum Progesterone EIA kit, using diluted extracts instead of serum or plasma. The cross-reactivity from steroides other than progesterone is less than $1 \%$ except for: 11 a-hydroxy-progesterone $(66.0 \%)$, 5-Pregnan-3bol-20-one (16.0\%), 5b-pregnan-3, 20-dione (4.5\%), 5a-Pregnan-3, 20-dione (3.3\%) and Deoxy-corticosterone acetate $(3.0 \%)$. The range of the assay was from 382 to $7632 \mathrm{nmol} / \mathrm{kg}$. The absorbance was measured by EIA reader (MCC/340 Labsistem Multiskan).

The intra-assay coefficient of variation (CV) was $3.59 \%(n=5)$ and $12.56 \%(n=5)$ for the concentration of 5950 and $1329 \mathrm{nmol} / \mathrm{kg}$, respectively; the interassay $\mathrm{CV}$ was $7.03 \%(\mathrm{n}=5)$ and $14.65 \%(\mathrm{n}=5)$ at the concentration 5969 and $1097 \mathrm{nmol} / \mathrm{kg}$, respectively.

\section{Plasma progesterone analysis}

Plasma progesterone analysis was performed by following the original instructions of the kit. The range of the assay was from 1.6 to $31.8 \mathrm{nmol} / \mathrm{L}$.

Measurement of the water content in faeces

Water content was measured in the faeces of the animals with permanent diarrhoea, and in faecal samples from two healthy animals. Approximately $2 \mathrm{~g}$ of fresh samples were dried at $+105^{\circ} \mathrm{C}$ (drying apparatus STE 17 Chirana) until constant weight. The percentage of water was calculated from the difference between fresh and dry weight.

\section{Statistical evaluation}

Results were considered significant at the level $\mathrm{P}<0.05$. The data of gestagen concentration and water content in faeces were analysed by Student's t-test, plasma and faecal gestagen concentrations compared by correlation coefficient ( $\mathrm{r}$ ). Statistical package MS Excel version 5.0, statistical function STDEVP was used. Faecal values higher than $7632 \mathrm{nmol} / \mathrm{kg}$ were considered as $7632 \mathrm{nmol} / \mathrm{kg}$ and plasma values higher than $31.8 \mathrm{nmol} / \mathrm{L}$ were considered as $31.8 \mathrm{nmol} / \mathrm{L}$. Results of faecal gestagen concentrations from 4 pregnant animals suffering from diarrhoea were excluded from statistical analysis. 


\section{Results}

Mean faecal gestagen and plasma progesterone concentrations in sows during the oestrous cycle, during the first three weeks of pregnancy and in animals with diarrhoea are presented in Tables 1, 2, 3, 4, and 5 .

Low faecal gestagen concentrations were observed from the beginning till the 6th day of oestrous cycle. From the 8th till the 17th day concentrations were high, thereafter they started to decrease gradually and were low again on the 20th and 21 st day of oestrous cycle. In pregnant sows faecal gestagen concentrations gradually increased from the insemination till the14th day and remained high from that day on. Similar pattern was also found in plasma progesterone concentrations. Faecal gestagen concentration in pregnant animals on 20th and 21 st day was significantly higher $(\mathrm{P}<0.01)$ than in nonpregnant animals at the same period. Significant $(\mathrm{P}<0.01)$ positive correlation was found comparing faecal gestagens and plasma progesterone concentrations during the oestrous cycle $(r=0.74)$ and during the first three weeks of pregnancy $(r=0.97)$.

Table 1

Faecal gestagen concentrations $(\mathrm{nmol} / \mathrm{kg})$ in sows during the oestrous cycle

\begin{tabular}{|c|c|c|c|c|c|c|c|c|c|c|c|c|c|c|}
\hline & \multicolumn{10}{|c|}{ Day of oestrous cycle } \\
\hline & 0 & 2 & 4 & 6 & 8 & 10 & 12 & 14 & 16 & 17 & 18 & 19 & 20 & 21 \\
\hline Mean & 1303 & 1126 & 2059 & 2400 & 6766 & 7632 & 7632 & 7632 & 7632 & 7037 & 5819 & 4611 & 2148 & 1961 \\
\hline SD & 227 & 156 & 67 & 229 & 591 & 0 & 0 & 0 & 0 & 595 & 1813 & 1930 & 668 & 91 \\
\hline SE & 161 & 111 & 47 & 162 & 419 & 0 & 0 & 0 & 0 & 422 & 1286 & 1369 & 474 & 65 \\
\hline
\end{tabular}

Table 2

Plasma progesterone concentrations $(\mathrm{nmol} / \mathrm{L})$ in sows during the oestrous cycle

\begin{tabular}{|c|c|c|c|c|c|c|c|c|c|c|c|c|c|c|}
\hline & \multicolumn{10}{|c|}{ Day of oestrous cycle } \\
\hline & 0 & 2 & 4 & 6 & 8 & 10 & 12 & 14 & 16 & 17 & 18 & 19 & 20 & 21 \\
\hline Mean & 5.2 & 8.7 & 13.2 & 24.2 & 31.0 & 30.5 & 31.8 & 31.8 & 28.8 & 15.7 & 10.0 & 9.4 & 9.3 & 17.8 \\
\hline SD & 2.8 & 0.5 & 1.1 & 1.9 & 0.8 & 1.3 & 0 & 0 & 3.0 & 2.1 & 0.2 & 0.2 & 0.7 & 2.4 \\
\hline SE & 2.0 & 0.3 & 0.8 & 1.3 & 0.6 & 0.9 & 0 & 0 & 2.1 & 1.5 & 0.1 & 0.1 & 0.5 & 1.7 \\
\hline
\end{tabular}

Table 3

Faecal gestagen concentrations $(\mathrm{nmol} / \mathrm{kg}$ ) in sows during the first three weeks of pregnancy

\begin{tabular}{|c|c|c|c|c|c|c|c|c|c|c|c|c|c|c|}
\hline & \multicolumn{10}{|c|}{ Day of pregnancy } \\
\hline & 0 & 2 & 4 & 6 & 8 & 10 & 12 & 14 & 16 & 17 & 18 & 19 & 20 & 21 \\
\hline Mean & 1365 & 1376 & 1886 & 3145 & 5764 & 5793 & 6473 & 7369 & 7602 & 7499 & 7595 & 7591 & 7624 & 7468 \\
\hline SD & 856 & 529 & 700 & 873 & 1819 & 2075 & 1882 & 831 & 94 & 421 & 116 & 129 & 26 & 352 \\
\hline SE & 258 & 159 & 211 & 263 & 548 & 625 & 567 & 250 & 28 & 127 & 35 & 39 & 8 & 106 \\
\hline
\end{tabular}

Table 4

Plasma progesterone concentrations $(\mathrm{nmol} / \mathrm{L})$ in sows during the first three weeks of pregnancy

\begin{tabular}{|c|c|c|c|c|c|c|c|c|c|c|c|c|c|c|}
\hline & \multicolumn{10}{|c|}{ Day of pregnancy } \\
\hline & 0 & 2 & 4 & 6 & 8 & 10 & 12 & 14 & 16 & 17 & 18 & 19 & 20 & 21 \\
\hline Mean & 3.5 & 5.2 & 9.7 & 14.3 & 21.0 & 26.2 & 27.0 & 27.5 & 28.1 & 30.7 & 31.5 & 30.7 & 31.0 & 31.2 \\
\hline SD & 1.5 & 2.4 & 2.5 & 2.8 & 3.8 & 6.3 & 8.0 & 7.4 & 6.6 & 2.6 & 0.9 & 3.5 & 2.4 & 1.8 \\
\hline SE & 0.4 & 0.7 & 0.7 & 0.8 & 1.2 & 1.9 & 2.4 & 2.2 & 2.0 & 0.8 & 0.3 & 1.1 & 0.7 & 0.5 \\
\hline
\end{tabular}


In faeces of two animals with diarrhoea mean water content was $73.27 \%$ (SD 4.56; SE 1.22) and $72.74 \%$ (SD 1.98; SE 0.53) respectively. Values were significantly higher $(\mathrm{P}<0.01)$ than in two healthy animals where water content was $65.26 \%$ (SD 4.56; SE 1.22) and $65.93 \%$ (SD 3.08; SE 0.82).

Table 5

Faecal gestagen concentration $(\mathrm{nmol} / \mathrm{kg})$ in pregnant animals with diarrhoea on several days after oestrus

\begin{tabular}{|c|c|c|c|c|c|c|c|c|c|c|c|c|c|c|}
\hline & \multicolumn{10}{|c|}{ Day of pregnancy } \\
\hline animal & 0 & 2 & 4 & 6 & 8 & 10 & 12 & 14 & 16 & 17 & 18 & 19 & 20 & 21 \\
\hline 1 & 3018 & 843 & 636 & 2922 & 7632 & 6176 & 3441 & 3428 & 7632 & 7632 & 5654 & 3962 & 7632 & 7632 \\
\hline 2 & 388 & 464 & 1113 & 1259 & 1832 & 1189 & 2210 & 989 & 1953 & 2499 & 3046 & 1313 & 1968 & 1781 \\
\hline 3 & 652 & 480 & 1196 & 1396 & 4678 & 7339 & 2748 & 3717 & 6541 & 5959 & 3543 & 3638 & 5625 & 3288 \\
\hline 4 & 576 & 986 & 1301 & 1755 & 4252 & 5059 & 3571 & 6525 & 7632 & 7632 & 6449 & 5473 & 4846 & 4153 \\
\hline
\end{tabular}

Table 6

Plasma progesterone concentration ( $\mathrm{nmol} / \mathrm{L})$ in pregnant animals with diarrhoea on several days after oestrus

\begin{tabular}{|c|c|c|c|c|c|c|c|c|c|c|c|c|c|c|}
\hline & \multicolumn{10}{|c|}{ Day of pregnancy } \\
\hline animal & 0 & 2 & 4 & 6 & 8 & 10 & 12 & 14 & 16 & 17 & 18 & 19 & 20 & 21 \\
\hline 1 & 2.3 & 5.7 & 9.8 & 12.0 & 14.4 & 27.5 & 25.4 & 30.4 & 31.8 & 31.8 & 31.8 & 28.4 & 31.8 & 31.8 \\
\hline 2 & 3.6 & 2.8 & 16.1 & 23.6 & 26.6 & 29.2 & 29.2 & 31.8 & 26.4 & 29.0 & 31.8 & 31.8 & 31.8 & 31.8 \\
\hline 3 & 1.6 & 7.6 & 16.6 & 20.3 & 20.0 & 25.4 & 25.4 & 26.4 & 29.3 & 31.8 & 29.8 & 31.8 & 28.4 & 30.6 \\
\hline 4 & 4.7 & 2.4 & 4.8 & 15.8 & 23.1 & 24.0 & 23.8 & 31.8 & 31.8 & 31.8 & 31.8 & 31.8 & 31.8 & 31.8 \\
\hline
\end{tabular}

Legend:

1,2 ; sows with permanent diarrhoea

3,4 ; sows with temporary diarrhoea

italics; days of sampling when diarrhoea was observed

\section{Discussion}

Changes in faecal gestagen (progesterone and its metabolites) concentration during the oestrous cycle and early pregnancy show the pattern typical for progesterone concentration changes in blood (Wang et al. 1985; Choi et al.1986). Significant positive correlation between faecal gestagen and plasma progesterone values indicates that the measurement of progesterone and its metabolites in faeces using Ovucheck 96 Well Plasma/Serum Progesterone EIA kit gives an accurate insight into the progesterone status in sows. Significant difference in faecal gestagen concentration between pregnant and non-pregnant animals on 20th and 21st day shows that this is a suitable method for pregnancy detection.

In animals suffering from diarrhoea faecal gestagen levels were low and the changes in gestagen concentrations were different from those in normal animals. No data could be found to explain the influence of diarrhoea on faecal gestagen content. During the digestive disorders water and electrolyte secretion is stimulated, reabsorption aggravated and the gut content diluted. Because the comparison of gestagen concentration in dry and fresh matter is not significantly different, dilution is probably not the only reason for low gestagen values. Massive peristaltic waves transport the gut content with the gestagens in the bile faster than in normal digestion. This could be another reason for lower gestagen concentration in gut content. 
Conclusion could be made that in animals with diarrhoea or other digestive disorders the measurement of faecal progesterone and its metabolites is not appropriate method for reproductive status determination in sows.

The study indicates that measurement of faecal gestagens in sows by using Ovucheck 96 Well Plasma/Serum Progesterone EIA kit is suitable for progesterone status detection in healthy animals, but is inappropriate in animals with diarrhoea.

\section{Acknowledgements}

The authors are very thankful to Prof. Elmar Bamberg from the Veterinary University in Vienna and to dr. David

P. Eckersall from the Faculty of Veterinary Medicine in Glasgow for their comments and suggestions.

\section{References}

BUSCH, W., BAMBERG, E. 1990: Trächtigkeitsdiagnose beim Schaf. Tierärztl. Umsch. 45: 430-434

CHOI, H. S., HOIS, J., BAMBERG, E. 1986: Hormonanalytische Trächtigkeitsdiagnose beim Schwein. Wien. Tierärztl. Mschr. 73: 94-96

ECKERSALL, P. D., HARVEY, M. J. A. 1987: The use of bovine plasma progesterone ELISA kit to measure progesterone in equine, ovine and canine plasmas. Vet. Rec. 120: 5-8

HULTEN, F., ZHANG, B. R., FORSBERG, M., DALIN, A. M. 1995: Applying a progesterone assay to faecal samples collected from sows during the oestrous cycle. Reprod. Dom. Anim. 30: 101-105

MÖSTL, E., LEHMANN, H., WENZEL, U. 1993: Gestagens in the feces of mink and cats for monitoring corpus luteum activity. J. Reprod. Fert. (Suppl) 47: 540-541

PALME, R., MÖSTL, E., BAMBERG, E., LORIN, D., ARBEITER, K. 1989: Sicherheit der Trächtigkeitsdiagnose bei der Stute mittels Eestrogenbestimmung im Kot. Prakt. Tierarzt 70: 43-44

PALME, R., FISCHER, P., SCHILDORFER, H., ISMAIL, M. N. 1996: Excretion of infused 14C-steroid hormones via faeces and urine in domestic livestock. Anim. Repr. Sci. 43: 43-63

PALME, R., MÖSTL, E., BREM, G.. SCHELLANDER, K., BAMBERG, E. 1997: Faecal metabolites of infused 14C-progesterone in domestic livestock. Reprod. Dom. Anim. 32: 199-206

RUOFF, W. L., DZIUK, P. J. 1994: Absorption and metabolism of estrogens from the stomach and duodenum of pigs. Dom. Anim. Endocrinol. 11: 197-208

SAFAR-HERMANN, N., ISMAIL, M. N., CHOI, H. S., MÖSTL, E., BAMBERG, E. 1987: Pregnancy diagnosis in zoo animals by estrogen determination in feces. Zoo Biol. 6: 189-193

SCHWARZENBERGER, F., BAMBERG, E., MÖSTL, E.1990: Monitoring of the oestrous cycle in farm animals by measuring gestagens in faeces. Proceedings of the Vlll International Congress on Hormonal Steroids. Hague, 1p

SCHWARZENBERGER, F., TOMÁŠOVÁ, K., HOLEČKOVÁ, D., MATERN, B., MÖSTL, E. 1996: Measurement of fecal steroids in the black rhinoceros (Diceros bicornis) using group-specific enzyme immunoassays for 20-oxo-pregnanes. Zoo Biol. 15: 159-171

SYMONDS, H. W., PRIME, G. R., PULLAR, R. A. 1994: Preliminary evidence for the enterohepatic circulation of progesterone in the pig. Brit. Vet. J. 150: 585-593

SZENCI. O., TAVERNE, M. A. M., PALME, R., BERTOTI, B., MERICSI, I. 1993: Evaluation of ultrasonography and determination of unconjugated oestrogen in feces for the diagnosis of pregnancy in pigs. Vet. Rec. 132: 510-512

TAYLOR, V. 1971: The excretion of steroid hormone metabolites in bile and feces. Vitam. Horm. 29: 201-285

WANG, R.X., SUN, Y., JIAO, S.X., ZHAO, S.J., QIAN, Y.X., YANG, S.F., DING, L.M. 1985: Serum progesterone levels of Fengjing sows during pregnancy. Acta Vet. Zootech. Sin. 3: 148-153

WASSER, S. K., MONFORT, S. L., WILDT, D. E. 1991: Rapid extraction of fecal steroids for measuring reproductive cyclicity and early pregnancy in free-ranging yellow baboons (Papio cynocephalus cynocephalus). J. Rep. Fert. 92: 415-423

WASSER, S. K., RISLER, L.. STEINER. R. A. 1988: Excreted steroids in primate feces over the menstrual cycle and pregnancy. Biol. Reprod. 39: 862-872

YOUNGBLOOD, M. A., WILLIAMS, J. F. 1987: Using estrone sulphate concentrations to detect pregnancies. Vet. Med. 82: 1036-1043 